\title{
microRNAs in Human Cancer
}

\author{
Thalia A. Farazi, Jessica I. Hoell, Pavel Morozov, and Thomas Tuschl \\ Howard Hughes Medical Institute, Laboratory of RNA Molecular Biology, The Rockefeller \\ University, New York, NY, 10065, USA
}

Thomas Tuschl: ttuschl@mail.rockefeller.edu

\section{Abstract}

Mature microRNAs (miRNAs) are single-stranded RNA molecules of 20-23-nucleotide (nt) length that control gene expression in many cellular processes. These molecules typically reduce the translation and stability of mRNAs, including those of genes that mediate processes in tumorigenesis, such as inflammation, cell cycle regulation, stress response, differentiation, apoptosis, and invasion. miRNA targeting is initiated through specific base-pairing interactions between the $5^{\prime}$ end ("seed" region) of the miRNA and sites within coding and untranslated regions (UTRs) of mRNAs; target sites in the 3' UTR lead to more effective mRNA destabilization. Since miRNAs frequently target hundreds of mRNAs, miRNA regulatory pathways are complex. To provide a critical overview of miRNA dysregulation in cancer, we first discuss the methods currently available for studying the role of miRNAs in cancer and then review miRNA genomic organization, biogenesis, and mechanism of target recognition, examining how these processes are altered in tumorigenesis. Given the critical role miRNAs play in tumorigenesis processes and their disease specific expression, they hold potential as therapeutic targets and novel biomarkers.

\section{Keywords}

microRNA; Cancer; mRNA destabilization; 3' UTR; Genomics; Deep sequencing; Posttranscriptional gene regulation

\section{1 miRNA Overview}

miRNAs were originally shown to be important in timing of larval development in $C$. elegans, leading to the identification of the miRNAs lin-4 and let-7[1,2]. Our initial understanding of miRNA-mRNA target recognition came from observations of sequence complementarity of the lin-4 RNA to multiple conserved sites within the lin-143' UTR [1, 3]; molecular genetic analysis had shown that this complementarity was required for the repression of lin-14 by lin-4 [4]. Homologues of let-7 or lin-4/mir-125 were thereafter shown to have temporal expression patterns in other organisms, including mammals, and to regulate mammalian development [5-8]. Given their integral role in development, it was no surprise that miRNAs were soon found to be important in tumorigenesis, and since their discovery close to 5,000 publications associate miRNAs to cancer, including over 1,000 reviews (recent examples include [9-11]). miRNAs were initially linked to tumorigenesis due to their apparent proximity to chromosomal breakpoints [12] and their dysregulated expression levels in many malignancies $[13,14]$.

\footnotetext{
(C) Springer Science+Business Media Dordrecht 2013

Correspondence to: Thomas Tuschl, ttuschl@mail. rockefeller.edu.

${ }^{*} \mathrm{~T}$. T. is cofounder of and scientific advisor to Alnylam Pharmaceuticals and scientific advisor to Regulus Therapeutics.
} 
Given the wealth of rapidly accumulating information implicating miRNAs in cancer, to allow the reader to critically assess the reports exploring the function of miRNAs in malignancies, we first review the methods used to study the expression and role of miRNAs in tumors, and then review the evidence that relates miRNA genomic organization, biogenesis, target recognition and function to tumorigenesis. An overview of miRNA cistronic expression and sequence similarity allows a better understanding of the regulation of miRNA expression and the factors contributing to technical limitations in accuracy of miRNA detection. Understanding the regulatory potential of miRNAs based on sequence similarity families and miRNA abundance allows evaluation of which miRNAs are important regulators of tumorigenesis pathways.

\subsection{Methods for Studying miRNA Genetics and Expression}

\subsection{1 miRNA Profiling}

The main methods currently used for miRNA profiling are sequencing, microarray and realtime RT-PCR based approaches (reviewed in [15-17]). The input material initially used for these studies comprised high quality preserved fresh frozen samples, but recently it has been possible to obtain reproducible and comparable profiles using formalin-fixed paraffinembedded tissues (FFPE), making these archived tumor collections accessible for study [1820]. Microarrays generally provide fold-changes in miRNA expression between samples, with members of miRNA sequence families prone to cross-hybridization [21-24]. More recently, calibration cocktails of synthetic miRNAs were used in array experiments to derive absolute abundance of miRNAs [25]. RT-PCR methods are lower throughput and require normalization (i.e. candidate reference genes including other small noncoding RNAs [26, 27]). Mean expression normalization has been suggested as an alternative RT-PCR normalization method for reduction of technical variation to allow appreciation of biological changes [28]. If external miRNA standards are used for quantification (i.e. [29, 30]), the most abundant miRNA, which may vary in length due to $3^{\prime}$ end heterogeneity, should be used as a calibration standard. Sequencing methods, besides their obvious potential to identify new miRNAs, editing and mutation events, estimate miRNA abundance based on frequency of sequence reads (e.g. [5, 7, 8, 31-34]). Given the dramatic increase in sequencing power, bar-coding samples can allow multiple specimens to be processed at the same time, reducing the cost and effort of profiling, and paving the way for large specimen studies [34-36]. Ligation biases between miRNAs and 5' and $3^{\prime}$ adapters for RT-PCR amplification exist in sequencing methods, and miRNA read frequencies may not always reflect the absolute expression levels, but these variations are irrelevant when monitoring fold-changes between samples. A study with a synthetic pool of 770 miRNA sequences showed that overall, these biases do not prevent identification of miRNAs, and allowed estimation of these biases [36]. For example, certain miRNAs could be over-represented due to higher ligation efficiency (such as miR-21, which was $~ 2$-fold over-represented), while other miRNAs could be under-represented (such as miR-31, which was $>5$-fold underrepresented). However, given the increasing depth of sequencing, most under-represented miRNAs are identified with sufficient sequence reads to allow for a statistically significant comparison across parallel processed samples.

Recent studies have compared the results obtained using multiple platforms [37]. A study of miRNA expression in liposarcoma revealed excellent agreement between bar-coded next generation sequencing and microarray profiles [38], while another study of miRNA expression in breast cancer showed good agreement between bar-coded sequencing and another hybridization-based method, Northern blotting [39].

Finally, choosing the appropriate statistical analysis to evaluate the data depends on the methodology used to obtain the profiles, ranging from established SAM analysis for 
microarray data [40], to newly developed techniques for sequencing data [34, 41, 42]. Recent in situ hybridization (ISH) advances allowed sensitive detection of miRNAs in heterogeneous tissues, defining miRNA cellular localization [43-45]. The potential of miRNA localization to suggest function for a subpopulation of cells was demonstrated early on, as in the case of $1 s y-6$ expressed in less than ten neurons in C. elegans controlling left/ right asymmetry [46].

\subsection{2 miRNA Databases and Validation}

It is critical to know which miRNAs are validated and have the potential to regulate cellular functions, especially given the frequent revisions of the miRNA database, miRBase (www.mirbase.org) [47], and the dramatic increase in the number of novel and re-annotated miRNAs through the use of deep-sequencing technologies. It is extremely challenging to establish the validity of novel miRNAs, particularly when their definition is based on a handful of sequence reads. The latest release of miRBase (version 17) includes 1,424 human miRNA precursors. Compared to version 16, version 17 includes 385 novel human miRNA precursors, 45 name changes, 1 sequence revision, and the removal of 2 precursors. Given the recent explosion in acquisition of next generation sequencing profiles, miRBase has now added features to allow evaluation of microRNA annotation [48]. The database mapped reads from short RNA deep-sequencing experiments to miRNAs and developed web interfaces to view these mappings. This is an important step in characterizing the newly identified miRNAs as prototypical miRNAs (consisting of a hairpin structure and processing sites consistent with RNase III cleavage steps).

The challenge of constantly revising and curating existing databases based on newly acquired sequencing data is illustrated in two recent studies re-evaluating mouse and human miRNAs. A recent study of 60 million small RNA sequence reads generated from a variety of adult and embryonic mouse tissues confirmed 398 annotated miRNA genes and identified 108 novel miRNA genes but was unable to find sequencing evidence for 150 previously annotated mouse miRNAs. Ectopic expression of the confirmed and newly identified miRNA hairpin sequences yielded small RNAs with the classical miRNA features but failed to support other previously annotated sequences (of the 17 tested miRNAs with no read evidence, only one yielded a single sequence read, while of 28 tested miRNAs with insufficient number of reads, only 4 were verified) [49]. A more recent study has reannotated human miRNAs based on read evidence from over 1,000 human samples [39] miRNAs were curated both on the basis of read counts, as well as patterns compatible with traditional miRNA processing, re-defining prototypical miRNAs (557 precursors, corresponding to 1,112 mature and star sequences (miRNA*, described in the following section), miR-451 and miR-618 being the only miRNAs without a star sequence). 269 not yet reported star sequences were added (compared to miRBase 16), putative miRNAs from miRBase, for which read evidence was not obtained, were ignored, and specific miRNAs were renamed according to the read ratio between mature and star sequences. The importance of curated miRNA databases is especially evident in assessing the statistical significance of differentially expressed miRNAs to identify potential biomarkers based on microarray studies. Including miRNAs without strong read evidence in such comparisons could skew the results.

\subsection{Mechanisms of Alteration of miRNA Levels in Malignancy}

We review miRNA biogenesis (Fig. 1.1) and illustrate which steps of the biogenesis pathway are linked to malignancy, starting from miRNA genomic localization, transcriptional regulation, processing steps and post-transcriptional modification. There is evidence supporting the association of the first three processes and/or the factors that control 
them with tumorigenesis, whereas evidence relating post-transcriptional miRNA modifications to cancer is not clear-cut.

\subsubsection{General Principles of miRNA Genomic Organization}

miRNAs are frequently expressed as polycistronic transcripts. To date, 1,424 human miRNA precursor sequences have been deposited in miRBase [47]. Approximately one-third (497) of these miRNAs are located in 156 clusters, each measuring $51 \mathrm{~kb}$ in the human genome ( $51 \mathrm{~kb}$ being the longest distance between miRNAs belonging to the same cluster, Fig. 1.2). These miRNA clusters are co-expressed based on evidence from miRNA profiling data from a variety of tissues and cell lines [22, 33, 34, 49]. The genomic organization of representative oncogenic (miR-17 and miR-21) and tumor suppressor (let-7 and miR-141) sequence families (described in following section) is illustrated in Fig. 1.2. Presentation of miRNA profiles in the form of expression clusters provides a readily interpretable summary of expression data and stresses the importance of cistronic expression regulation; dysregulation of one member of the cluster should be accompanied by similar dysregulation of other cluster members [39]. Since miRNA genes are frequently multi-copy, determining the relative contribution of each genomic location to mature miRNA expression is challenging.

\subsubsection{Alterations in Genomic miRNA Copy Numbers and Location}

Changes in miRNA expression between normal and tumor specimens are often attributed to the location of miRNAs in regions of chromosomal instability (amplification, translocation or deletion), or nearby chromosomal breakpoints, initially locating $52.5 \%$ of miRNA genes in cancer-associated regions or fragile sites [12]. The miRNA cluster mir-15a/16-1 is located in a frequently deleted genomic locus containing a putative tumor suppressor-containing region in chronic B-cell lymphocytic leukemia (B-CLL) [50]. Other examples include deletion of let-7g/mir-135-1 in a variety of human malignancies [12], amplification of mir-17-92 cluster in lymphoma [51], translocation of mir-17-92 in T-cell acute lymphoblastic leukemia (T-ALL) [52], and amplification of mir-26a in glioblastoma [53].

\subsubsection{Alterations in miRNA Transcriptional Regulation}

Some autonomously expressed miRNA genes have promoter regions that allow miRNAs to be highly expressed in a cell-type-specific manner, and can even drive high levels of oncogenes in cases of chromosomal translocation. The mir-142 gene, strongly expressed in hematopoietic cells, is located on chromosome 17 and was found at the breakpoint junction of a $\mathrm{t}(8 ; 17)$ translocation to $M Y C$, which causes an aggressive B-cell leukemia [54]. The translocated $M Y C$ gene, which was also truncated at the first exon, was located only four nucleotides from the $3^{\prime}$ end of the mir-142 precursor, placing it under the control of the upstream mir-142 promoter. In an animal model for Hepatocellular Carcinoma (HCC), a similar event placed $C-M Y C$ downstream of the mir-122a promoter which is active only in hepatocytes [55].

Many transcription factors regulate miRNA expression in a tissue-specific and disease statespecific fashion, and some miRNAs are regulated by well-established tumor suppressor or oncogene pathways such as TP53, MYC, and RAS (reviewed in [56]). The miRNA and its transcriptional regulators can participate in complex feedback regulation loops. Examples include the TP53 regulated mir-34a [57, 58], the RAS regulated mir-21 [33, 59, 60] and the MYC regulated mir-17-92 gene cluster [61, 62].

miRNA dysregulation has also been linked to changes in epigenetic regulation, such as the methylation status of miRNA genes, which results in alterations in their expression levels 
[63, 64]. Examples of methylated miRNA genes include mir-127 in bladder cancer cells [65] and mir-9-1 in breast cancer [66].

\subsection{4 miRNA Biogenesis Pathway in Tumorigenesis}

miRNA biogenesis has been reviewed extensively [56, 67-73] (Fig. 1.1). miRNA pathway components could either be mis-expressed in tumors or mutated (reviewed in [74, 75]). Posttranscriptional regulation of miRNAs themselves through RNA editing or terminal modifications was shown to alter miRNA targeting, processing and stability, but connection of these modifications to tumorigenesis has not yet been definitive (reviewed in [56, 75, 76]).

1.3.4.1 miRNA Biogenesis-Briefly, the mature 20-23-nt miRNA molecules are excised in a multi-step process from primary transcripts (pri-miRNAs) that contain one or more 70nt hairpin miRNA precursors (pre-miRNA) and have their own promoters or share promoters with coding genes. These hairpin structures are recognized in the nucleus by DGCR8, a double-stranded RNA-binding protein (dsRBP), and RNASEN, also known as RNase III Drosha, and excised to yield pre-miRNAs. These molecules are subsequently transported by XPO5 (exportin 5) to the cytoplasm where they are further processed by DICER1 (Dicer) in complex with the dsRBPs TARBP2 (TRBP) and/or PRKRA to yield an RNA duplex processing intermediate composed of mature miRNA and miRNA* sequences. Some miRNAs bypass the general miRNA processing and their maturation can be independent of DGCR8 and RNASEN, such as miR-320 or miR-484 [77], or are DICER1 independent, such as erythropoiesis-related miR-451 [78, 79]. DGCR8 and RNASEN independent miRNAs include mirtrons and tailed mirtrons, which release their pre-miRNA by splicing and exonuclase trimming [80, 81]. A recent review describes alternative processing pathways, and enumerates settings in which alternative miRNA pathways contribute to distinct phenotypes among miRNA biogenesis mutants [82].

While the mature miRNA is loaded into the Argonaute/EIF2C (AGO) proteins that are at the core of the miRNA-containing ribonucleoprotein complex (miRNP), sometimes also referred to as RNA-induced silencing complex (miRISC), the miRNA* is released and degraded. miR-451 is generated from an unusual hairpin structure that is processed by AGO2 instead of DICER1 [78, 79]. The miRNPs contain a member of the AGO family (14), which binds the miRNA and mediates target mRNA recognition. Several other RBPs have been implicated in miRNA biogenesis, including DHX9, DDX6, MOV10, DDX5, DDX17, LIN28A, HNRNPA1 and KSRP [56, 83]. Following transcription, miRNAs can be modified by several enzymes, including deaminases, resulting in miRNA editing, and terminal uridylyl transferases (TUTases), leading to pre-miRNA uridylylation, potentially affecting the amount and ratio of miRNA and miRNA* (e.g. [84]), or their sequences (e.g. [85]).

1.3.4.2 Alterations in RNASEN/DGCR8 and DICER1/TARBP2-Inhibition of the miRNA biogenesis pathway leads to severe developmental defects and is lethal in many organisms (reviewed earlier in [86], recent examples include [77, 78]), and perturbations of this pathway predispose to tumorigenesis [87]. Initial miRNA expression profiling experiments suggested that miRNAs are less abundant in tumors compared to their normal tissue counterparts [14], leading to the proposal that miRNAs are predominantly tumor suppressors rather than oncogenes. Quantification of absolute miRNA levels, not only relative abundance, in miRNA profiling methods is necessary to clarify these observations. $27 \%$ of various tumors are found to have a hemizygous deletion of the gene that encodes DICER1 [88]. Global knockdown of mature miRNAs by targeting DICER1, RNASEN and its cofactor DGCR8 increases the oncogenic potential of already transformed cancer cell 
lines and accelerates tumor formation [87]. Reductions in the amount of DICER1 resulting in impaired miRNA processing have also been shown to increase the rate of tumor formation in two different cancer mouse models, a K-RAS-driven lung cancer [88] and an $\mathrm{Rb}$-driven retinoblastoma [89]. DICER1 is therefore considered a haploinsufficient tumor suppressor, requiring partial deletion for its associated tumorigenesis phenotype [89]. The phosphorylation of the DICER1 cofactor TARBP2 by the mitogen-activated protein kinase Erk enhances pre-miRNA processing of oncogenic miRNAs, such as miR-21, and decreases production of tumor suppressor let-7a [90]. Moreover, TARBP2 is mutated in some colon and gastric cancers with microsatellite instability, and TARBP2 frameshift mutations correlate with DICER1 destabilization; in cell lines and xenografts with TARBP2 mutations, reintroduction of wild type TARBP2/DICER1 slowed tumor growth [91, 92]. Finally, DICER1 was also recently implicated as a metastasis suppressor (reviewed in [93]).

1.3.4.3 Alterations in Other Pathway- Related RBPs-Firstly, expression of LIN28A blocks processing of tumor suppressor pri- and pre-let-7 [94-98], thus maintaining expression of genes that drive self-renewal and proliferation (reviewed in [99]); tumors that express LIN28A were indeed shown to be poorly differentiated and more aggressive than LIN28A-negative tumors. Secondly, the helicases DDX5 and DDX17 are thought to stimulate processing of one third of all murine miRNAs by acting as a scaffold and recruiting factors to the RNASEN complex and thereby promoting pri-miRNA processing [100]. Association of DDX17 and DDX5 RNA helicases through interactions mediated by the tumor suppressor TP53 with the RNASEN/DGCR8 complex facilitates the conversion of pri- to pre-miRNAs [101]. Specifically, the DDX5-mediated interaction of the RNASEN complex with the tumor suppressor TP53 was shown to have a stimulatory effect on the tumor suppressor pri-miR-16-1, pri-miR-143 and pri-miR-145 processing in response to DNA damage in cancer cells [101]. Thus, TP53 mutations, often observed in malignancies, led to a decrease in pre-miRNA production. Thirdly, oncogenic SMADs, downstream effectors of the TGF- $\beta$ superfamily pathways, have been shown to control RNASENmediated miRNA maturation through interaction with DDX5, promoting expression of oncogenic miR-21 [102]. KSRP promotes the biogenesis of a subset of miRNAs, including let-7a, by serving as a component of both DICER1 and RNASEN complexes affecting proliferation, apoptosis and differentiation [103]. In a final example, inactivating mutations of XPO5 in tumors with microsatellite instability result in the nuclear retention of miRNAs [104]. Restoration of XPO5 function reverses the impaired export of premiRNAs and has tumor suppressor features.

\subsection{Dysregulation of miRNA-mRNA Target Recognition}

\subsection{1 miRNA Function/Mechanism}

As described above, miRNAs function through the AGO proteins, containing both RNAbinding domains and RNase H domains (reviewed in [105]). The four human Ago genes are coexpressed and bind to miRNAs irrespective of their sequence. AGO2, in contrast to the other members, retains an active RNase $\mathrm{H}$ domain and thus is able to directly cleave target RNAs with extensive complementarity to the bound miRNAs. The assembly of the miRNP complex involves multiple AGO conformational transitions captured in a series of crystal structures (reviewed in [106]). The mRNA target is recognized by pairing of the miRNA seed region (position 2-8) to complementary sequences located mainly in the target $3^{\prime}$ UTR, but also in the coding regions. Target mRNA recognition and regulation involves members of the GW182/TNRC6 family. TNRC6 proteins act at the effector step of silencing, downstream of AGO proteins, and play a crucial role in miRNA silencing in animals (reviewed in [107]). Proteomic approaches identified additional AGO-interacting proteins, some of which likely represent mRNA-interacting partners that co-purified with miRNA- 
targeted mRNPs; their function in RNA silencing processes and potentially tumorigenesis remains to be established.

In mammalian cells under steady state conditions, miRNAs have been shown to destabilize targeted transcripts [108-111] through a variety of mechanisms, including de-capping and deadenylation; target mRNA and protein abundance changes track closely [108, 109, 112, 113]. These studies also showed that miRNAs destabilize mRNAs preferably through binding sites located in their $3^{\prime}$ UTRs [114-118]. Ribosome profiling studies demonstrated that the ribosome density of miRNA targets was unaltered, while changes in miRNA levels were inversely correlated to mRNA and protein abundance, emphasizing the role of miRNAs in regulation of mRNA stability but not translation [119]. Translational regulation by miRNA targeting is considered to predominantly act at the level of translation initiation. Identification of miRNA/mRNA ribonucleoprotein components in processing bodies (Pbodies) also implies their role in mRNA storage and RNA turnover. An excellent recent review describes the different mechanisms implicated in miRNA function, highlighting the different experiments supporting translational repression versus mRNA decay and the evolution in our current thinking [107].

\subsubsection{Organization of miRNAs into Sequence Families}

Certain miRNAs share sequence similarity in regions that are critical for mRNA target recognition, specifically the seed region, and are best viewed as a family when considering mRNA target regulation and functional consequences of altered miRNA expression. miRNAs can be grouped in sequence families, based not only on their seed sequence similarity but also overall sequence similarity given that the miRNA $3^{\prime}$ end also contributes to miRNA targeting, although to a lesser extent (reviewed in [68]) (Fig. 1.2). Changes in the overall abundance of miRNA sequence families relate directly to target regulation. In a MYC-driven B-cell lymphoma mouse model, a conditional knockout of the oncogenic miR-17-92 gene cluster induces apoptosis, which can be reduced by reintroduction of only one of the four sequence families produced from the cluster [120].

\subsection{3 miRNA-mRNA Stoichiometry}

The majority of miRNA profiling studies do not provide an estimate of miRNA abundance, which is critical in our understanding of the role of miRNA-mRNA mediated regulation in tumorigenesis. Only the most abundantly expressed miRNAs, occupy a substantial fraction of their available mRNA target sites and affect target mRNA stability [118]. Abundant miRNAs that behave as "switches", turned on or off during the tumorigenesis process, as shown in developmental processes, have the most significant regulatory potential, given that miRNAs usually only lead to modest 1.5 - to 4-fold regulation of their target expression $[112,113,115]$. However, given that specific mRNAs are subject to regulation by multiple miRNAs of unrelated families, cumulative effects of lower expressed miRNAs may be relevant $[67,121,122]$. Furthermore, in the rare circumstance that miRNAs share near perfect complementarity to mRNAs, they may act in a siRNA-like catalytic mode, cleaving mRNA targets even at low miRNA abundance. To conclude, the interplay between miRNAs expressed in particular tissues, the levels of their respective expressed targets, as well as other post-transcriptional gene regulatory mechanisms (such as regulation by RBPs or other competing interactions - see below) is likely responsible for balancing miRNA conferred regulation.

\subsubsection{Changes in the miRNA Targets}

The binding sites of miRNAs in mRNAs can be altered through a variety of mechanisms, such as point mutations, translocations, shortening of the $3^{\prime}$ UTR, competition with other RBPs or decoy molecules for mRNA binding. Point mutations in miRNA targets can both 
create or destroy a miRNA binding site [123-125]. Chromosomal translocations can remove miRNA binding sites from their regulated oncogenes, such as in the case of let-7 targeting of the 3' UTR of the Hmga2 gene [126]. Shortening of the 3' UTR through alternative polyadenylation can relax miRNA mediated regulation of known oncogenes, such as IGF2BP1/IMP1, and lead to oncogenic transformation [127], as does use of decoy pseudogenes, as in the case of PTEN, by saturating miRNA binding sites [128]. Finally, cooperativity or competition of miRNAs for mRNA target site binding with other RBPs, such as ELAVL1 (HuR), DND1 and PUM1, can also de-repress target expression [129132]. This topic is discussed in a recent review [83].

\subsection{Cancer Tissues Have Distinct miRNA Profiles}

We will first discuss the state of current miRNA profile databases, and then explore the issue of tissue heterogeneity in the tissue profiles before summarizing the role of miRNA dysregulation in malignancies.

\subsection{1 miRNA Cancer Database}

The development of miRNA microarrays, RT-PCR platforms and deep sequencing methodologies has resulted in an exponential acquisition of miRNA profiles. Some of the published miRNA profiles are available in the NCBI Gene Expression Omnibus, similarly to mRNA profiles (other resources include www.microrna.org, http://www.mirz.unibas.ch). Larger cancer and blood-borne disease collections have recently been published using various platforms [133-135]. However, there is no database or viewer that allows for crossplatform comparison of existing data.

\subsubsection{Tissue Heterogeneity}

Tissues are generally composed of multiple cell types, each with their distinct gene expression program. Disease not only alters the expression programs of the affected cell type, but often also its cell type composition. To best separate these effects in the profiling of heterogeneous tumor samples, it may be useful to profile tumor cell lines, and individual cell types that may be present in a tumor sample, or define miRNA cellular localization by performing RNA ISH. Figure 1.3 compares miRNA abundance profiles of normal breast, an estrogen receptor positive invasive ductal breast carcinoma, the estrogen receptor positive ductal cell line MCF7, human fat and blood [38, 39]. Strikingly, we can model the profile of a human cancer by simply combining tumor cell line and human fat profiles at equal ratio. This demonstrates that the MCF7 tumor cell line may be a good disease model for deciphering miRNA regulatory networks, as it expresses many of the miRNAs present in the predominant tumor derived cell type and highlights the need for individual cell type miRNA profiles.

\subsection{3 miRNAs as Tumor Suppressors and Oncogenes}

miRNA dysregulation could be used as a diagnostic tool even if the particular miRNAs do not serve any regulatory function. Alternatively, miRNA dysregulation could drive tumorigenesis, through the roles miRNAs can adopt as tumor suppressors or oncogenes. miRNAs that are up- or down-regulated in malignancies are respectively referred to as oncogenic or tumor-suppressor miRNAs, sometimes even if there is no evidence for their causative role in tumorigenesis. Some of the most commonly dysregulated miRNAs are summarized in Table 1.1 (reviewed in [11]).

Functional studies performed in cancer cell lines or mouse models of various malignancies through over-expression or knockdown of miRNAs have supported a role for some of these miRNAs in tumorigenesis. Over-expression of tumor suppressor miRNAs, such as let-7g, 
reduced tumor burden in a K-RAS murine lung cancer model [172]. Over-expression of the oncogenic mir-17-92 gene cluster led to a lymphoproliferative disorder, and higher level expression of the cluster in MYC-driven B-cell lymphomas dramatically increased tumorigenicity $[62,173]$. Overexpression of another oncogene, miR-21, frequently highly expressed in solid and hematologic malignancies, resulted in a pre-B malignant lymphoid like phenotype whereas subsequent miR-21 inactivation in the same model led to apoptosis and tumor regression [174]. Transgenic mice models with loss and gain of function of miR-21 combined with a model of lung cancer confirmed the role of miR-21 as an enhancer of tumorigenesis when over-expressed, or a partial protector when genetically deleted [59]. Ectopic expression of miR-155 in bone marrow induced polyclonal pre-B cell proliferation progressing to B-cell leukemia or myeloproliferation in mice $[175,176]$.

Metastasis-related miRNAs have been identified in various malignancies mainly from cell line and xenograft experiments (reviewed in [177]). Examples include breast cancer-related miR-10b, miR-9, miR-31 and miR-335 among others. The interesting regulatory roles of these miRNAs cannot easily be validated in large clinical studies. Two clinical studies with long-term follow-up data instead identified miR-210 to be associated with tumor aggressiveness $[178,179]$, pointing to difficulties reconciling cell line, xenograft model and patient materials, due to tissue heterogeneity discussed earlier, the heterogeneous nature of the malignancy and timing of clinical specimen acquisition. Tumor miRNA profiles cannot dissect contributions from sub-populations of cells that may be important for tumor characteristics such as metastasis, while cell line miRNA profiles cannot capture the cellular interactions from supporting cell types in the tumor microenvironment. Patient samples are often collected at time of diagnosis, by which time a tumor is already well established and cannot unravel early changes that may be critical in tumor initiation or later changes important in metastasis.

\subsection{4 miRNA-Regulated Pathways}

The observed effects of miRNA mis-expression on tumor initiation, maintenance or metastasis can be explained by the mRNA targets and pathways they regulate, which include known tumor suppressors and oncogenes (reviewed in [11]). miRNAs regulate a large number of genes, some estimates reporting miRNA regulation of up to $60 \%$ of the human genome, making it challenging to attribute a phenotype after mis-expression of a particular miRNA through its action on only a subset of targets $[111,180]$. If a few of these targets control rate-limiting steps in the studied tumorigenesis processes within the specified tissues and cell types, such as metastasis, then miRNA regulation of a handful of targets could potentially explain the phenotype resulting from miRNA mis-expression [181].

Examples of miRNA regulated cancer pathways include differentiation, apoptosis, proliferation, and stem cell maintenance, a process important for disease relapse and/or metastasis. The skeletal muscle-specific miR-206 blocks human rhabdomyosarcoma growth in mouse xenograft models by inducing myogenic differentiation [30], while the mir-141/200a cluster is critical in the epithelial to mesenchymal transition (EMT) in various malignancies (reviewed in [182]). Sustained expression of endogenous mir-17-92 cluster is required to suppress apoptosis in Myc-driven B-cell lymphomas in a conditional knockout allele of mir-17-92 cluster [120]. TP53-regulated, ectopically expressed miR-34 induced cell cycle arrest in both primary and tumor derived cell lines, downregulating genes promoting cell cycle progression (reviewed in [58]). In a final example of miRNA regulated cancer pathways, isolation of a subset of highly tumorigenic breast cancer cells that were thought to have stemness properties showed that these cells do not express let-7 family members and that expression of let-7 or its known target RAS leads to loss of self renewal [183]. 


\subsection{Alterations of miRNA Sequence}

miRNA dysregulation could be a result of mutations in miRNA genes in well-conserved regions in their mature sequence affecting mRNA targeting, or the remainder of the miRNA precursor potentially affecting processing and stability of the mature miRNA (reviewed in [75]). For example, a mutation in the seed region of mir-96 was shown to lead to hearing loss in a mouse model [184] and was identified in families with non-syndromic progressive sensorineural hearing loss [185], while a point mutation in the viral mir- $K 5$ precursor stem loop was shown to interfere with its processing and reduce mature miR-K5 accumulation [186]. Germline deletion of the mir-17-92 gene cluster was another recent example causing skeletal growth defects in humans [187]. If miRNAs are drivers of oncogenic and tumor suppressors pathways we would expect to find miRNA mutations that can also be causative of the disease. So far the only mutation identified in a miRNA that could lead to malignancy is miR-16, where a germline mutation potentially affects miR-16 biogenesis and abundance in a kindred with familial CLL [188] and New Zealand black mice that naturally develop CLL-like disease [189]. Single nucleotide polymorphisms (SNPs), located both in precursor and mature miRNA sequences, have been examined in the context of disease risk for various malignancies but have not been validated as causative (reviewed in [75]).

\section{7 miRNA Target Identification}

The currently available target prediction databases (reviewed in [68]) do not easily allow to prioritizing the involvement of reported targets in certain phenotypes, thus necessitating the selection of a few targets from a list of hundreds for further study and validation, based on a priori knowledge of potentially involved biological pathways. Since the prediction algorithms do not always produce identical target lists, use of multiple algorithms and comparison or intersection of their results narrows the list to higher confidence targets. Targets are only relevant to a specific phenotype if they are expressed in the studied tissue, an issue not addressed by most computational prediction algorithms. Recently, new algorithms are trying to prioritize computationally predicted targets using integrated miRNA and mRNA profiles [134]. Biochemical identification methods in cell lines and tissues are being established and further refine our understanding of miRNA-mRNA target binding recognition. These methods involve two approaches: over-expression or down-regulation of studied miRNAs followed by assessment of transcriptome-wide mRNA levels by mRNA microarray analysis (e.g. [118]) or deep sequencing technology after immunoprecipitation of miRNAs and mRNAs complexed with AGO, the main component of the miRNA effector complex, to not only identify mRNA targets, but also localize their precise binding sites $[190,191]$.

\section{8 miRNAs as Diagnostics}

miRNAs demonstrated their potential as diagnostic tumor markers early on, when their profiles were shown to correlate with the tumor embryonic origin, thus defining tumors of unknown origin indistinguishable by histology and assigned based on clinical information [14]. miRNA expression patterns have been linked to clinical outcomes, given that miRNAs modulate tumor behavior such as tumor progression and metastasis. Expression of let-7 is downregulated in non-small cell lung cancer patients [192] and is associated with poor prognosis $[125,193]$, whereas a miRNA signature was identified to be associated with prognosis in CLL [188]. Advances in miRNA detection, such as ISH or RT-PCR, may allow miRNAs to be used as diagnostic and prognostic markers in the clinic. 


\section{9 miRNAs as Therapeutics}

Because miRNAs affect the expression of multiple genes and thereby tune multiple points in disease pathways, miRNAs and their regulated genes, represent interesting drug targets. Antisense oligonucleotide targeting experiments in human cell lines, mice [117, 194-197] and non-human primates [198] have demonstrated the feasibility of manipulating miRNA levels. miR-143 was initially shown to promote adipocyte differentiation and could be a target for therapies in obesity and metabolic diseases [194]. Alternatively, "miRNA sponges" have been exploited to reduce miRNA expression in mammalian cells and mouse models by using RNA transcripts expressed from strong promoters containing miRNAcomplementary binding sites (reviewed in [199]). Systemic administration of antisense oligonucleotide therapeutics to miR-122, a liver-enriched miRNA, in mice and primates was shown to alter lipid metabolism and hepatitis $\mathrm{C}$ viral load, resulting in reduced liver damage $[117,195-197,200,201]$. At the same time, systemic delivery of a miRNA mimic for miR-26a in a murine model of HCC reduced tumor size [148]. The new and exciting advances in delivery of miRNA inhibitors and mimics hold the promise of quickly translating our knowledge of miRNAs into treating disease.

\section{Acknowledgments}

We thank Iddo Ben-Dov for sharing his unpublished data and Miguel Brown and Aleksandra Mihailovic for assistance with figure generation. We thank Markus Hafner, Kemal Akat, and Neil Renwick for their help with editing the manuscript. T.F. is supported by Grant \#UL1 TR000043 from the National Center for Research Resources and the National Center for Advancing Translational Sciences (NCATS), NIH. J.I.H. is supported by the Deutsche Forschungsgemeinschaft. T.T. is an HHMI investigator, and work in his laboratory was supported by NIH grant MH08442, RC1CA145442 and the Starr Cancer Foundation. We apologize to those investigators whose work we could not cite due to space constraints.

\section{References}

1. Lee RC, Feinbaum RL, Ambros V. The C. elegans heterochronic gene lin-4 encodes small RNAs with antisense complementarity to lin-14. Cell. 1993; 75:843-854. [PubMed: 8252621]

2. Reinhart BJ, Slack FJ, Basson M, et al. The 21-nucleotide let-7 RNA regulates developmental timing in Caenorhabditis elegans. Nature. 2000; 403:901-906. [PubMed: 10706289]

3. Wightman B, Ha I, Ruvkun G. Posttranscriptional regulation of the heterochronic gene lin-14 by lin-4 mediates temporal pattern formation in C. elegans. Cell. 1993; 75:855-862. [PubMed: 8252622]

4. Wightman B, Burglin TR, Gatto J, et al. Negative regulatory sequences in the lin-14 3' -untranslated region are necessary to generate a temporal switch during Caenorhabditis elegans development. Genes Dev. 1991; 5:1813-1824. [PubMed: 1916264]

5. Lagos-Quintana M, Rauhut R, Lendeckel W, et al. Identification of novel genes coding for small expressed RNAs. Science. 2001; 294:853-858. [PubMed: 11679670]

6. Lagos-Quintana M, Rauhut R, Yalcin A, et al. Identification of tissue-specific microRNAs from mouse. Curr Biol. 2002; 12:735-739. [PubMed: 12007417]

7. Lau NC, Lim LP, Weinstein EG, et al. An abundant class of tiny RNAs with probable regulatory roles in Caenorhabditis elegans. Science. 2001; 294:858-862. [PubMed: 11679671]

8. Lee RC, Ambros V. An extensive class of small RNAs in Caenorhabditis elegans. Science. 2001; 294:862-864. [PubMed: 11679672]

9. Garofalo M, Croce CM. microRNAs: master regulators as potential therapeutics in cancer. Annu Rev Pharmacol Toxicol. 2010; 51:25-43. [PubMed: 20809797]

10. Medina PP, Slack FJ. microRNAs and cancer: an overview. Cell Cycle. 2008; 7:2485-2492. [PubMed: 18719380]

11. Ventura A, Jacks T. MicroRNAs and cancer: short RNAs go a long way. Cell. 2009; 136:586-591. [PubMed: 19239879] 
12. Calin GA, Sevignani C, Dumitru CD, et al. Human microRNA genes are frequently located at fragile sites and genomic regions involved in cancers. Proc Natl Acad Sci U S A. 2004; 101:29993004. [PubMed: 14973191]

13. Calin GA, Liu CG, Sevignani C, et al. MicroRNA profiling reveals distinct signatures in B cell chronic lymphocytic leukemias. Proc Natl Acad Sci U S A. 2004; 101:11755-11760. [PubMed: 15284443]

14. Lu J, Getz G, Miska EA, et al. MicroRNA expression profiles classify human cancers. Nature. 2005; 435:834-838. [PubMed: 15944708]

15. Aravin A, Tuschl T. Identification and characterization of small RNAs involved in RNA silencing. FEBS Lett. 2005; 579:5830-5840. [PubMed: 16153643]

16. Creighton CJ, Reid JG, Gunaratne PH. Expression profiling of microRNAs by deep sequencing. Brief Bioinform. 2009; 10:490-497. [PubMed: 19332473]

17. Meyer SU, Pfaffl MW, Ulbrich SE. Normalization strategies for microRNA profiling experiments: a 'normal' way to a hidden layer of complexity? Biotechnol Lett. 2010; 32(12):1777-1788. [PubMed: 20703800]

18. Lawrie $\mathrm{CH}$, Soneji S, Marafioti T, et al. MicroRNA expression distinguishes between germinal center B cell-like and activated B cell-like sub-types of diffuse large B cell lymphoma. Int J Cancer. 2007; 121:1156-1161. [PubMed: 17487835]

19. Weng $\mathrm{L}, \mathrm{Wu} \mathrm{X}, \mathrm{Gao} \mathrm{H}$, et al. MicroRNA profiling of clear cell renal cell carcinoma by wholegenome small RNA deep sequencing of paired frozen and formalin-fixed, paraffin-embedded tissue specimens. J Pathol. 2010; 222:41-51. [PubMed: 20593407]

20. Xi Y, Nakajima G, Gavin E, et al. Systematic analysis of microRNA expression of RNA extracted from fresh frozen and formalin-fixed paraffin-embedded samples. RNA. 2007; 13:1668-1674. [PubMed: 17698639]

21. Barad O, Meiri E, Avniel A, et al. MicroRNA expression detected by oligonucleotide microarrays: system establishment and expression profiling in human tissues. Genome Res. 2004; 14:24862494. [PubMed: 15574827]

22. Baskerville S, Bartel DP. Microarray profiling of microRNAs reveals frequent coexpression with neighboring miRNAs and host genes. RNA. 2005; 11:241-247. [PubMed: 15701730]

23. Thomson JM, Parker JS, Hammond SM. Microarray analysis of miRNA gene expression. Methods Enzymol. 2007; 427:107-122. [PubMed: 17720481]

24. Nelson PT, Baldwin DA, Scearce LM, et al. Microarray-based, high-throughput gene expression profiling of microRNAs. Nat Methods. 2004; 1:155-161. [PubMed: 15782179]

25. Bissels U, Wild S, Tomiuk S, et al. Absolute quantification of microRNAs by using a universal reference. RNA. 2009; 15:2375-2384. [PubMed: 19861428]

26. Peltier HJ, Latham GJ. Normalization of microRNA expression levels in quantitative RT-PCR assays: identification of suitable reference RNA targets in normal and cancerous human solid tissues. RNA. 2008; 14:844-852. [PubMed: 18375788]

27. Fiedler SD, Carletti MZ, Christenson LK. Quantitative RT-PCR methods for mature microRNA expression analysis. Methods Mol Biol. 2010; 630:49-64. [PubMed: 20300990]

28. Mestdagh P, Van Vlierberghe P, De Weer A, et al. A novel and universal method for microRNA RT-qPCR data normalization. Genome Biol. 2009; 10:R64. [PubMed: 19531210]

29. Smith RD, Brown B, Ikonomi P, et al. Exogenous reference RNA for normalization of real-time quantitative PCR. Biotechniques. 2003; 34:88-91. [PubMed: 12545545]

30. Taulli R, Bersani F, Foglizzo V, et al. The muscle-specific microRNA miR-206 blocks human rhabdomyosarcoma growth in xenotransplanted mice by promoting myogenic differentiation. $\mathrm{J}$ Clin Invest. 2009; 119:2366-2378. [PubMed: 19620785]

31. Berezikov E, Thuemmler F, van Laake LW, et al. Diversity of microRNAs in human and chimpanzee brain. Nat Genet. 2006; 38:1375-1377. [PubMed: 17072315]

32. Houbaviy HB, Murray MF, Sharp PA. Embryonic stem cell-specific microRNAs. Dev Cell. 2003; 5:351-358. [PubMed: 12919684]

33. Landgraf $P$, Rusu M, Sheridan R, et al. A mammalian microRNA expression atlas based on small RNA library sequencing. Cell. 2007; 129:1401-1414. [PubMed: 17604727] 
34. Witten D, Tibshirani R, Gu SG, et al. Ultra-high throughput sequencing-based small RNA discovery and discrete statistical biomarker analysis in a collection of cervical tumours and matched controls. BMC Biol. 2010; 8:58. [PubMed: 20459774]

35. Vigneault F, Sismour AM, Church GM. Efficient microRNA capture and bar-coding via enzymatic oligonucleotide adenylation. Nat Methods. 2008; 5:777-779. [PubMed: 19160512]

36. Hafner M, Renwick N, Brown M, et al. RNA-ligase- dependent biases in miRNA representation in deep-sequenced small RNA cDNA libraries. RNA. 2011; 17:1697-1712. [PubMed: 21775473]

37. Git A, Dvinge H, Salmon-Divon M, et al. Systematic comparison of microarray profiling, real-time PCR, and next-generation sequencing technologies for measuring differential microRNA expression. RNA. 2010; 16:991-1006. [PubMed: 20360395]

38. Ugras S, Brill E, Jacobsen A, et al. Small RNA sequencing and functional characterization reveals microRNA-143 tumor suppressor activity in liposarcoma. Cancer Res. 2011; 71:5659-5669. [PubMed: 21693658]

39. Farazi TA, Horlings HM, Ten Hoeve JJ, et al. MicroRNA sequence and expression analysis in breast tumors by deep sequencing. Cancer Res. 2011; 71:4443-4453. [PubMed: 21586611]

40. Tusher VG, Tibshirani R, Chu G. Significance analysis of microarrays applied to the ionizing radiation response. Proc Natl Acad Sci U S A. 2001; 98:5116-5121. [PubMed: 11309499]

41. Berninger P, Gaidatzis D, van Nimwegen E, et al. Computational analysis of small RNA cloning data. Methods. 2008; 44:13-21. [PubMed: 18158128]

42. Robinson MD, McCarthy DJ, Smyth GK. EdgeR: a Bioconductor package for differential expression analysis of digital gene expression data. Bioinformatics. 2010; 26:139-140. [PubMed: 19910308]

43. Nelson PT, Baldwin DA, Kloosterman WP, et al. RAKE and LNA-ISH reveal microRNA expression and localization in archival human brain. RNA. 2006; 12:187-191. [PubMed: 16373485]

44. Pena JT, Sohn-Lee C, Rouhanifard SH, et al. miRNA in situ hybridization in formaldehyde and EDC-fixed tissues. Nat Methods. 2009; 6:139-141. [PubMed: 19137005]

45. Sempere LF, Christensen M, Silahtaroglu A, et al. Altered MicroRNA expression confined to specific epithelial cell subpopulations in breast cancer. Cancer Res. 2007; 67:11612-11620. [PubMed: 18089790]

46. Johnston RJ, Hobert O. A microRNA controlling left/right neuronal asymmetry in Caenorhabditis elegans. Nature. 2003; 426:845-849. [PubMed: 14685240]

47. Griffiths-Jones S, Saini HK, van Dongen S, et al. miRBase: tools for microRNA genomics. Nucleic Acids Res. 2008; 36:D154-D158. [PubMed: 17991681]

48. Kozomara A, Griffiths-Jones S. miRBase: integrating microRNA annotation and deep-sequencing data. Nucleic Acids Res. 2010; 39:D152-D157. [PubMed: 21037258]

49. Chiang HR, Schoenfeld LW, Ruby JG, et al. Mammalian microRNAs: experimental evaluation of novel and previously annotated genes. Genes Dev. 2010; 24:992-1009. [PubMed: 20413612]

50. Calin GA, Dumitru CD, Shimizu M, et al. Frequent deletions and down-regulation of micro- RNA genes miR15 and miR16 at 13q14 in chronic lymphocytic leukemia. Proc Natl Acad Sci U S A. 2002; 99:15524-15529. [PubMed: 12434020]

51. Tagawa H, Seto M. A microRNA cluster as a target of genomic amplification in malignant lymphoma. Leukemia. 2005; 19:2013-2016. [PubMed: 16167061]

52. Mavrakis KJ, Wolfe AL, Oricchio E, et al. Genome-wide RNA-mediated interference screen identifies miR-19 targets in Notch-induced T-cell acute lymphoblastic leukaemia. Nat Cell Biol. 2010; 12:372-379. [PubMed: 20190740]

53. Huse JT, Brennan C, Hambardzumyan D, et al. The PTEN-regulating microRNA miR-26a is amplified in high-grade glioma and facilitates gliomagenesis in vivo. Genes Dev. 2009; 23:13271337. [PubMed: 19487573]

54. Gauwerky CE, Huebner K, Isobe M, et al. Activation of MYC in a masked $t(8 ; 17)$ translocation results in an aggressive B-cell leukemia. Proc Natl Acad Sci U S A. 1989; 86:8867-8871. [PubMed: 2682663]

55. Etiemble J, Moroy T, Jacquemin E, et al. Fused transcripts of c-myc and a new cellular locus, hcr in a primary liver tumor. Oncogene. 1989; 4:51-57. [PubMed: 2644611] 
56. Krol J, Loedige I, Filipowicz W. The wide-spread regulation of microRNA biogenesis, function and decay. Nat Rev Genet. 2010; 11:597-610. [PubMed: 20661255]

57. Chang TC, Wentzel EA, Kent OA, et al. Transactivation of miR-34a by p53 broadly influences gene expression and promotes apoptosis. Mol Cell. 2007; 26:745-752. [PubMed: 17540599]

58. He L, He X, Lowe SW, et al. microRNAs join the p53 network - another piece in the tumoursuppression puzzle. Nat Rev Cancer. 2007; 7:819-822. [PubMed: 17914404]

59. Hatley ME, Patrick DM, Garcia MR, et al. Modulation of K-Ras-dependent lung tumorigenesis by MicroRNA-21. Cancer Cell. 2010; 18:282-293. [PubMed: 20832755]

60. Huang TH, Wu F, Loeb GB, et al. Up-regulation of miR-21 by HER2/neu signaling promotes cell invasion. J Biol Chem. 2009; 284:18515-18524. [PubMed: 19419954]

61. O’Donnell KA, Wentzel EA, Zeller KI, et al. c-Myc-regulated microRNAs modulate E2F1 expression. Nature. 2005; 435:839-843. [PubMed: 15944709]

62. He L, Thomson JM, Hemann MT, et al. A microRNA polycistron as a potential human oncogene. Nature. 2005; 435:828-833. [PubMed: 15944707]

63. Han L, Witmer PD, Casey E, et al. DNA methylation regulates MicroRNA expression. Cancer Biol Ther. 2007; 6:1284-1288. [PubMed: 17660710]

64. Saito Y, Jones PA. Epigenetic activation of tumor suppressor microRNAs in human cancer cells. Cell Cycle. 2006; 5:2220-2222. [PubMed: 17012846]

65. Saito Y, Liang G, Egger G, et al. Specific activation of microRNA-127 with downregulation of the proto-oncogene BCL6 by chromatin-modifying drugs in human cancer cells. Cancer Cell. 2006; 9:435-443. [PubMed: 16766263]

66. Lehmann U, Hasemeier B, Christgen M, et al. Epigenetic inactivation of microRNA gene hsa-mir9-1 in human breast cancer. J Pathol. 2008; 214:17-24. [PubMed: 17948228]

67. Bartel DP. MicroRNAs: genomics, biogenesis, mechanism, and function. Cell. 2004; 116:281-297. [PubMed: 14744438]

68. Bartel DP. MicroRNAs: target recognition and regulatory functions. Cell. 2009; 136:215-233. [PubMed: 19167326]

69. Brodersen P, Voinnet O. Revisiting the principles of microRNA target recognition and mode of action. Nat Rev Mol Cell Biol. 2009; 10:141-148. [PubMed: 19145236]

70. Carthew RW, Sontheimer EJ. Origins and mechanisms of miRNAs and siRNAs. Cell. 2009; 136:642-655. [PubMed: 19239886]

71. Ghildiyal M, Zamore PD. Small silencing RNAs: an expanding universe. Nat Rev Genet. 2009; 10:94-108. [PubMed: 19148191]

72. Kim VN, Han J, Siomi MC. Biogenesis of small RNAs in animals. Nat Rev Mol Cell Biol. 2009; 10:126-139. [PubMed: 19165215]

73. Winter J, Jung S, Keller S, et al. Many roads to maturity: microRNA biogenesis pathways and their regulation. Nat Cell Biol. 2009; 11:228-234. [PubMed: 19255566]

74. Kwak PB, Iwasaki S, Tomari Y. The microRNA pathway and cancer. Cancer Sci. 2010; 101(11): 2309-2315. [PubMed: 20726859]

75. Ryan BM, Robles AI, Harris CC. Genetic variation in microRNA networks: the implications for cancer research. Nat Rev Cancer. 2010; 10:389-402. [PubMed: 20495573]

76. Nishikura K. Functions and regulation of RNA editing by ADAR deaminases. Annu Rev Biochem. 2010; 79:321-349. [PubMed: 20192758]

77. Yi R, Pasolli HA, Landthaler M, et al. DGCR8-dependent microRNA biogenesis is essential for skin development. Proc Natl Acad Sci U S A. 2009; 106:498-502. [PubMed: 19114655]

78. Cheloufi S, Dos Santos CO, Chong MM, et al. A dicer-independent miRNA biogenesis pathway that requires Ago catalysis. Nature. 2010; 465:584-589. [PubMed: 20424607]

79. Yang JS, Maurin T, Robine N, et al. Conserved vertebrate mir-451 provides a platform for Dicerindependent, Ago2-mediated microRNA biogenesis. Proc Natl Acad Sci U S A. 2010; 107:15163-15168. [PubMed: 20699384]

80. Babiarz JE, Ruby JG, Wang Y, et al. Mouse ES cells express endogenous shRNAs, siRNAs, and other Microprocessor-independent, Dicer-dependent small RNAs. Genes Dev. 2008; 22:27732785. [PubMed: 18923076] 
81. Berezikov E, Chung WJ, Willis J, et al. Mammalian mirtron genes. Mol Cell. 2007; 28:328-336. [PubMed: 17964270]

82. Yang JS, Lai EC. Alternative miRNA biogenesis pathways and the interpretation of core miRNA pathway mutants. Mol Cell. 2011; 43:892-903. [PubMed: 21925378]

83. van Kouwenhove M, Kedde M, Agami R. MicroRNA regulation by RNA-binding proteins and its implications for cancer. Nat Rev Cancer. 2011; 11:644-656. [PubMed: 21822212]

84. Hagan JP, Piskounova E, Gregory RI. Lin28 recruits the TUTase Zcchc11 to inhibit let-7 maturation in mouse embryonic stem cells. Nat Struct Mol Biol. 2009; 16:1021-1025. [PubMed: 19713958]

85. Kawahara Y, Zinshteyn B, Chendrimada TP, et al. RNA editing of the microRNA-151 precursor blocks cleavage by the Dicer-TRBP complex. EMBO Rep. 2007; 8:763-769. [PubMed: 17599088]

86. Stefani G, Slack FJ. Small non-coding RNAs in animal development. Nat Rev Mol Cell Biol. 2008; 9:219-230. [PubMed: 18270516]

87. Kumar MS, Lu J, Mercer KL, et al. Impaired microRNA processing enhances cellular transformation and tumorigenesis. Nat Genet. 2007; 39:673-677. [PubMed: 17401365]

88. Kumar MS, Pester RE, Chen CY, et al. Dicer1 functions as a haploinsufficient tumor suppressor. Genes Dev. 2009; 23:2700-2704. [PubMed: 19903759]

89. Lambertz I, Nittner D, Mestdagh P, et al. Monoallelic but not biallelic loss of Dicer1 promotes tumorigenesis in vivo. Cell Death Differ. 2010; 17:633-641. [PubMed: 20019750]

90. Paroo Z, Ye X, Chen S, et al. Phosphorylation of the human microRNA-generating complex mediates MAPK/Erk signaling. Cell. 2009; 139:112-122. [PubMed: 19804757]

91. Melo SA, Ropero S, Moutinho C, et al. A TARBP2 mutation in human cancer impairs microRNA processing and DICER1 function. Nat Genet. 2009; 41:365-370. [PubMed: 19219043]

92. Garre P, Perez-Segura P, Diaz-Rubio E, et al. Reassessing the TARBP2 mutation rate in hereditary nonpolyposis colorectal cancer. Nat Genet. 2010; 42:817-818. author reply 818. [PubMed: 20877318]

93. Valastyan S, Weinberg RA. Metastasis suppression: a role of the Dice(r). Genome Biol. 2010; 11:141. [PubMed: 21118581]

94. Newman MA, Thomson JM, Hammond SM. Lin-28 interaction with the Let-7 precursor loop mediates regulated microRNA processing. RNA. 2008; 14:1539-1549. [PubMed: 18566191]

95. Piskounova E, Viswanathan SR, Janas M, et al. Determinants of microRNA processing inhibition by the developmentally regulated RNA-binding protein Lin28. J Biol Chem. 2008; 283:2131021314. [PubMed: 18550544]

96. Rybak A, Fuchs H, Smirnova L, et al. A feedback loop comprising lin-28 and let-7 controls pre-let7 maturation during neural stem-cell commitment. Nat Cell Biol. 2008; 10:987-993. [PubMed: 18604195]

97. Viswanathan SR, Daley GQ, Gregory RI. Selective blockade of microRNA processing by Lin28. Science. 2008; 320:97-100. [PubMed: 18292307]

98. Viswanathan SR, Powers JT, Einhorn W, et al. Lin28 promotes transformation and is associated with advanced human malignancies. Nat Genet. 2009; 41:843-848. [PubMed: 19483683]

99. Viswanathan SR, Daley GQ. Lin28: a microRNA regulator with a macro role. Cell. 2010; 140:445-449. [PubMed: 20178735]

100. Fukuda T, Yamagata K, Fujiyama S, et al. DEAD-box RNA helicase subunits of the Drosha complex are required for processing of rRNA and a subset of microRNAs. Nat Cell Biol. 2007; 9:604-611. [PubMed: 17435748]

101. Suzuki HI, Yamagata K, Sugimoto K, et al. Modulation of microRNA processing by p53. Nature. 2009; 460:529-533. [PubMed: 19626115]

102. Davis BN, Hilyard AC, Lagna G, et al. SMAD proteins control DROSHA-mediated microRNA maturation. Nature. 2008; 454(7200):56-61. [PubMed: 18548003]

103. Trabucchi M, Briata P, Garcia-Mayoral M, et al. The RNA-binding protein KSRP promotes the biogenesis of a subset of microRNAs. Nature. 2009; 459:1010-1014. [PubMed: 19458619] 
104. Melo SA, Moutinho C, Ropero S, et al. A genetic defect in exportin-5 traps precursor microRNAs in the nucleus of cancer cells. Cancer Cell. 2010; 18:303-315. [PubMed: 20951941]

105. Ender C, Meister G. Argonaute proteins at a glance. J Cell Sci. 2010; 123:1819-1823. [PubMed: 20484662]

106. Parker JS. How to slice: snapshots of Argonaute in action. Silence. 2010; 1:3. [PubMed: 20226069]

107. Huntzinger E, Izaurralde E. Gene silencing by microRNAs: contributions of translational repression and mRNA decay. Nat Rev Genet. 2011; 12:99-110. [PubMed: 21245828]

108. Linsley PS, Schelter J, Burchard J, et al. Transcripts targeted by the microRNA-16 family cooperatively regulate cell cycle progression. Mol Cell Biol. 2007; 27:2240-2252. [PubMed: 17242205]

109. Zhao Y, Ransom JF, Li A, et al. Dysregulation of cardiogenesis, cardiac conduction, and cell cycle in mice lacking miRNA-1-2. Cell. 2007; 129:303-317. [PubMed: 17397913]

110. Bagga S, Bracht J, Hunter S, et al. Regulation by let-7 and lin-4 miRNAs results in target mRNA degradation. Cell. 2005; 122:553-563. [PubMed: 16122423]

111. Lim LP, Lau NC, Garrett-Engele P, et al. Microarray analysis shows that some microRNAs downregulate large numbers of target mRNAs. Nature. 2005; 433:769-773. [PubMed: 15685193]

112. Baek D, Villen J, Shin C, et al. The impact of microRNAs on protein output. Nature. 2008; 455(7209):64-71. [PubMed: 18668037]

113. Selbach M, Schwanhausser B, Thierfelder N, et al. Widespread changes in protein synthesis induced by microRNAs. Nature. 2008; 455(7209):58-63. [PubMed: 18668040]

114. Grimson A, Farh KK, Johnston WK, et al. MicroRNA targeting specificity in mammals: determinants beyond seed pairing. Mol Cell. 2007; 27:91-105. [PubMed: 17612493]

115. Hausser J, Landthaler M, Jaskiewicz L, et al. Relative contribution of sequence and structure features to the mRNA binding of Argonaute/EIF2C-miRNA complexes and the degradation of miRNA targets. Genome Res. 2009; 19:2009-2020. [PubMed: 19767416]

116. Karginov FV, Conaco C, Xuan Z, et al. A bio-chemical approach to identifying microRNA targets. Proc Natl Acad Sci U S A. 2007; 104:19291-19296. [PubMed: 18042700]

117. Krützfeldt J, Rajewsky N, Braich R, et al. Silencing of microRNAs in vivo with 'antagomirs'. Nature. 2005; 438:685-689. [PubMed: 16258535]

118. Landthaler M, Gaidatzis D, Rothballer A, et al. Molecular characterization of human Argonautecontaining ribonucleoprotein complexes and their bound target mRNAs. RNA. 2008; 14:2580 2596. [PubMed: 18978028]

119. Guo H, Ingolia NT, Weissman JS, et al. Mammalian microRNAs predominantly act to decrease target mRNA levels. Nature. 2010; 466:835-840. [PubMed: 20703300]

120. Mu P, Han YC, Betel D, et al. Genetic dissection of the miR-17 92 cluster of microRNAs in Mycinduced B-cell lymphomas. Genes Dev. 2009; 23:2806-2811. [PubMed: 20008931]

121. Wu S, Huang S, Ding J, et al. Multiple microRNAs modulate p21Cip1/Waf1 expression by directly targeting its $3^{\prime}$ untranslated region. Oncogene. 2010; 29:2302-2308. [PubMed: 20190813]

122. Krek A, Grun D, Poy MN, et al. Combinatorial microRNA target predictions. Nat Genet. 2005; 37:495-500. [PubMed: 15806104]

123. Chin LJ, Ratner E, Leng S, et al. A SNP in a let-7 microRNA complementary site in the KRAS $3^{\prime}$ untranslated region increases non-small cell lung cancer risk. Cancer Res. 2008; 68:8535-8540. [PubMed: 18922928]

124. Jiang S, Zhang HW, Lu MH, et al. MicroRNA-155 functions as an OncomiR in breast cancer by targeting the suppressor of cytokine signaling 1 gene. Cancer Res. 2010; 70:3119-3127. [PubMed: 20354188]

125. Takamizawa J, Konishi H, Yanagisawa K, et al. Reduced expression of the let-7 microRNAs in human lung cancers in association with shortened postoperative survival. Cancer Res. 2004; 64:3753-3756. [PubMed: 15172979] 
126. Mayr C, Hemann MT, Bartel DP. Disrupting the pairing between let-7 and Hmga2 enhances oncogenic transformation. Science. 2007; 315:1576-1579. [PubMed: 17322030]

127. Mayr C, Bartel DP. Widespread shortening of 3' UTRs by alternative cleavage and polyadenylation activates oncogenes in cancer cells. Cell. 2009; 138:673-684. [PubMed: 19703394]

128. Poliseno L, Salmena L, Zhang J, et al. A coding- independent function of gene and pseudogene mRNAs regulates tumour biology. Nature. 2010; 465:1033-1038. [PubMed: 20577206]

129. Bhattacharyya SN, Habermacher R, Martine U, et al. Relief of microRNA-mediated translational repression in human cells subjected to stress. Cell. 2006; 125:1111-1124. [PubMed: 16777601]

130. Kim HH, Kuwano Y, Srikantan S, et al. HuR recruits let-7/RISC to repress c-Myc expression. Genes Dev. 2009; 23:1743-1748. [PubMed: 19574298]

131. Kedde M, Strasser MJ, Boldajipour B, et al. RNA-binding protein Dnd1 inhibits microRNA access to target mRNA. Cell. 2007; 131:1273-1286. [PubMed: 18155131]

132. Kedde M, van Kouwenhove M, Zwart W, et al. A Pumilio-induced RNA structure switch in p27-3' UTR controls miR-221 and miR-222 accessibility. Nat Cell Biol. 2010; 12:1014-1020. [PubMed: 20818387]

133. Volinia S, Galasso M, Costinean S, et al. Reprogramming of miRNA networks in cancer and leukemia. Genome Res. 2010; 20:589-599. [PubMed: 20439436]

134. Mestdagh P, Lefever S, Pattyn F, et al. The microRNA body map: dissecting microRNA function through integrative genomics. Nucleic Acids Res. 2011; 39(20):e136. [PubMed: 21835775]

135. Keller A, Leidinger P, Bauer A, et al. Toward the blood-borne miRNome of human diseases. Nat Methods. 2011; 8(10):841-843. [PubMed: 21892151]

136. Calin GA, Cimmino A, Fabbri M, et al. MiR-15a and miR-16-1 cluster functions in human leukemia. Proc Natl Acad Sci U S A. 2008; 105:5166-5171. [PubMed: 18362358]

137. Roush S, Slack FJ. The let-7 family of microRNAs. Trends Cell Biol. 2008; 18:505-516. [PubMed: 18774294]

138. Peter ME. Let-7 and miR-200 microRNAs: guardians against pluripotency and cancer progression. Cell Cycle. 2009; 8:843-852. [PubMed: 19221491]

139. Osada H, Takahashi T. let-7 and miR-17-92: small-sized major players in lung cancer development. Cancer Sci. 2011; 102:9-17. [PubMed: 20735434]

140. O'Day E, Lal A. MicroRNAs and their target gene networks in breast cancer. Breast Cancer Res. 2010; 12:201. [PubMed: 20346098]

141. Aqeilan RI, Calin GA, Croce CM. miR-15a and miR-16-1 in cancer: discovery, function and future perspectives. Cell Death Differ. 2010; 17:215-220. [PubMed: 19498445]

142. Finnerty JR, Wang WX, Hebert SS, et al. The miR-15/107 group of microRNA genes: evolutionary biology, cellular functions, and roles in human diseases. J Mol Biol. 2010; 402:491509. [PubMed: 20678503]

143. Mendell JT. miRiad roles for the miR-17-92 cluster in development and disease. Cell. 2008; 133:217-222. [PubMed: 18423194]

144. Uziel T, Karginov FV, Xie S, et al. The miR-17 92 cluster collaborates with the Sonic Hedgehog pathway in medulloblastoma. Proc Natl Acad Sci U S A. 2009; 106:2812-2817. [PubMed: 19196975]

145. Poliseno L, Salmena L, Riccardi L, et al. Identification of the miR-106b 25 microRNA cluster as a proto-oncogenic PTEN-targeting intron that cooperates with its host gene MCM7 in transformation. Sci Signal. 2010; 3:ra29. [PubMed: 20388916]

146. Jazbutyte V, Thum T. MicroRNA-21: from cancer to cardiovascular disease. Curr Drug Targets. 2010; 11:926-935. [PubMed: 20415649]

147. Sander S, Bullinger L, Klapproth K, et al. MYC stimulates EZH2 expression by repression of its negative regulator miR-26a. Blood. 2008; 112:4202-4212. [PubMed: 18713946]

148. Kota J, Chivukula RR, O'Donnell KA, et al. Therapeutic microRNA delivery suppresses tumorigenesis in a murine liver cancer model. Cell. 2009; 137:1005-1017. [PubMed: 19524505]

149. Visone R, Pallante P, Vecchione A, et al. Specific microRNAs are downregulated in human thyroid anaplastic carcinomas. Oncogene. 2007; 26:7590-7595. [PubMed: 17563749] 
150. Kim H, Huang W, Jiang X, et al. Integrative genome analysis reveals an oncomir/oncogene cluster regulating glioblastoma survivorship. Proc Natl Acad Sci U S A. 2010; 107:2183-2188. [PubMed: 20080666]

151. Cole KA, Attiyeh EF, Mosse YP, et al. A functional screen identifies miR-34a as a candidate neuroblastoma tumor suppressor gene. Mol Cancer Res. 2008; 6:735-742. [PubMed: 18505919]

152. Li N, Fu H, Tie Y, et al. miR-34a inhibits migration and invasion by down-regulation of c-Met expression in human hepatocellular carcinoma cells. Cancer Lett. 2009; 275:44-53. [PubMed: 19006648]

153. Gregory PA, Bracken CP, Bert AG, et al. MicroRNAs as regulators of epithelial-mesenchymal transition. Cell Cycle. 2008; 7:3112-3118. [PubMed: 18927505]

154. Nakada C, Matsuura K, Tsukamoto Y, et al. Genome-wide microRNA expression profiling in renal cell carcinoma: significant down-regulation of miR-141 and miR-200c. J Pathol. 2008; 216:418-427. [PubMed: 18925646]

155. Du Y, Xu Y, Ding L, et al. Down-regulation of miR-141 in gastric cancer and its involvement in cell growth. J Gastroenterol. 2009; 44:556-561. [PubMed: 19363643]

156. Adam L, Zhong M, Choi W, et al. miR-200 expression regulates epithelial-to-mesenchymal transition in bladder cancer cells and reverses resistance to epidermal growth factor receptor therapy. Clin Cancer Res. 2009; 15:5060-5072. [PubMed: 19671845]

157. Bendoraite A, Knouf EC, Garg KS, et al. Regulation of miR-200 family microRNAs and ZEB transcription factors in ovarian cancer: evidence supporting a mesothelial-to-epithelial transition. Gynecol Oncol. 2009; 116:117-125. [PubMed: 19854497]

158. Park SM, Gaur AB, Lengyel E, et al. The miR- 200 family determines the epithelial phenotype of cancer cells by targeting the E-cadherin repressors ZEB1 and ZEB2. Genes Dev. 2008; 22:894907. [PubMed: 18381893]

159. Hu X, Macdonald DM, Huettner PC, et al. A miR-200 microRNA cluster as prognostic marker in advanced ovarian cancer. Gynecol Oncol. 2009; 114:457-464. [PubMed: 19501389]

160. Gandellini P, Folini M, Longoni N. miR-205 Exerts tumor-suppressive functions in human prostate through down-regulation of protein kinase Cepsilon. Cancer Res. 2009; 69:2287-2295. [PubMed: 19244118]

161. Schaefer A, Jung M, Mollenkopf HJ, et al. Diagnostic and prognostic implications of microRNA profiling in prostate carcinoma. Int J Cancer. 2010; 126:1166-1176. [PubMed: 19676045]

162. Wiklund ED, Bramsen JB, Hulf T, et al. Coordinated epigenetic repression of the miR-200 family and miR-205 in invasive bladder cancer. Int J Cancer. 2011; 128:1327-1334. [PubMed: 20473948]

163. Iorio MV, Ferracin M, Liu CG, et al. MicroRNA gene expression deregulation in human breast cancer. Cancer Res. 2005; 65:7065-7070. [PubMed: 16103053]

164. Wu H, Zhu S, Mo YY. Suppression of cell growth and invasion by miR-205 in breast cancer. Cell Res. 2009; 19:439-448. [PubMed: 19238171]

165. Feber A, Xi L, Luketich JD, et al. MicroRNA expression profiles of esophageal cancer. J Thorac Cardiovasc Surg. 2008; 135:255-260. discussion 260. [PubMed: 18242245]

166. Iorio MV, Visone R, Di Leva G, et al. MicroRNA signatures in human ovarian cancer. Cancer Res. 2007; 67:8699-8707. [PubMed: 17875710]

167. Negrini M, Calin GA. Breast cancer metastasis: a microRNA story. Breast Cancer Res. 2008; 10:203. [PubMed: 18373886]

168. Ferretti E, De Smaele E, Po A, et al. MicroRNA profiling in human medulloblastoma. Int J Cancer. 2009; 124:568-577. [PubMed: 18973228]

169. Laios A, O’Toole S, Flavin R, et al. Potential role of miR-9 and miR-223 in recurrent ovarian cancer. Mol Cancer. 2008; 7:35. [PubMed: 18442408]

170. Ma L, Young J, Prabhala H, et al. miR-9, a MYC/MYCN-activated microRNA, regulates Ecadherin and cancer metastasis. Nat Cell Biol. 2010; 12:247-256. [PubMed: 20173740]

171. Sun Y, Wu J, Wu SH, et al. Expression profile of microRNAs in c-Myc induced mouse mammary tumors. Breast Cancer Res Treat. 2009; 118:185-196. [PubMed: 18777135] 
172. Kumar MS, Erkeland SJ, Pester RE, et al. Suppression of non-small cell lung tumor development by the let-7 microRNA family. Proc Natl Acad Sci. 2008; 105:3903-3908. [PubMed: 18308936]

173. Xiao C, Srinivasan L, Calado DP, et al. Lymphoproliferative disease and autoimmunity in mice with increased miR-17-92 expression in lymphocytes. Nat Immunol. 2008; 9:405-414. [PubMed: 18327259]

174. Medina PP, Nolde M, Slack FJ. OncomiR addiction in an in vivo model of microRNA-21induced pre-B-cell lymphoma. Nature. 2010; 467:86-90. [PubMed: 20693987]

175. Costinean S, Zanesi N, Pekarsky Y, et al. Pre-B cell proliferation and lymphoblastic leukemia/ high-grade lymphoma in E(mu)-miR155 transgenic mice. Proc Natl Acad Sci U S A. 2006; 103:7024-7029. [PubMed: 16641092]

176. O'Connell RM, Rao DS, Chaudhuri AA, et al. Sustained expression of microRNA-155 in hematopoietic stem cells causes a myeloproliferative disorder. J Exp Med. 2008; 205:585-594. [PubMed: 18299402]

177. Hurst DR, Edmonds MD, Welch DR. Metastamir: the field of metastasis-regulatory microRNA is spreading. Cancer Res. 2009; 69:7495-7498. [PubMed: 19773429]

178. Camps C, Buffa FM, Colella S, et al. hsa-miR- 210 is induced by hypoxia and is an independent prognostic factor in breast cancer. Clin Cancer Res. 2008; 14:1340-1348. [PubMed: 18316553]

179. Foekens JA, Sieuwerts AM, Smid M, et al. Four miRNAs associated with aggressiveness of lymph node-negative, estrogen receptor-positive human breast cancer. Proc Natl Acad Sci. 2008; 105:13021-13026. [PubMed: 18755890]

180. Friedman RC, Farh KK, Burge CB, et al. Most mammalian mRNAs are conserved targets of microRNAs. Genome Res. 2009; 19:92-105. [PubMed: 18955434]

181. Valastyan S, Benaich N, Chang A, et al. Concomitant suppression of three target genes can explain the impact of a microRNA on metastasis. Genes Dev. 2009; 23:2592-2597. [PubMed: 19875476]

182. Cano A, Nieto MA. Non-coding RNAs take centre stage in epithelial-to-mesenchymal transition. Trends Cell Biol. 2008; 18:357-359. [PubMed: 18585040]

183. Yu F, Yao H, Zhu P, et al. let-7 regulates self renewal and tumorigenicity of breast cancer cells. Cell. 2007; 131:1109-1123. [PubMed: 18083101]

184. Lewis MA, Quint E, Glazier AM, et al. An ENU-induced mutation of miR-96 associated with progressive hearing loss in mice. Nat Genet. 2009; 41:614-618. [PubMed: 19363478]

185. Mencia A, Modamio-Hoybjor S, Redshaw N, et al. Mutations in the seed region of human miR-96 are responsible for nonsyndromic progressive hearing loss. Nat Genet. 2009; 41:609613. [PubMed: 19363479]

186. Gottwein E, Cai X, Cullen BR. Expression and function of microRNAs encoded by Kaposi's sarcoma-associated herpesvirus. Cold Spring Harb Symp Quant Biol. 2006; 71:357-364. [PubMed: 17381317]

187. de Pontual L, Yao E, Callier P. Germline deletion of the miR-17 approximately 92 cluster causes skeletal and growth defects in humans. Nat Genet. 2011; 43(10):1026-1030. [PubMed: 21892160]

188. Calin GA, Ferracin M, Cimmino A, et al. A MicroRNA signature associated with prognosis and progression in chronic lymphocytic leukemia. N Engl J Med. 2005; 353:1793-1801. [PubMed: 16251535]

189. Raveche ES, Salerno E, Scaglione BJ, et al. Abnormal microRNA-16 locus with synteny to human 13q14 linked to CLL in NZB mice. Blood. 2007; 109:5079-5086. [PubMed: 17351108]

190. Chi SW, Zang JB, Mele A, et al. Argonaute HITS-CLIP decodes microRNA-mRNA interaction maps. Nature. 2009; 460:479-486. [PubMed: 19536157]

191. Hafner M, Landthaler M, Burger L, et al. Transcriptome-wide identification of RNA-binding protein and microRNA target sites by PAR-CLIP. Cell. 2010; 141:129-141. [PubMed: 20371350]

192. Johnson CD, Esquela-Kerscher A, Stefani G, et al. The let-7 MicroRNA represses cell proliferation pathways in human cells. Cancer Res. 2007; 67:7713-7722. [PubMed: 17699775]

193. Yanaihara N, Caplen N, Bowman E, et al. Unique microRNA molecular profiles in lung cancer diagnosis and prognosis. Cancer Cell. 2006; 9:189-198. [PubMed: 16530703] 
194. Esau C, Kang X, Peralta E, et al. MicroRNA-143 regulates adipocyte differentiation. J Biol Chem. 2004; 279:52361-52365. [PubMed: 15504739]

195. Krutzfeldt J, Kuwajima S, Braich R, et al. Specificity, duplex degradation and subcellular localization of antagomirs. Nucleic Acids Res. 2007; 35:2885-2892. [PubMed: 17439965]

196. Elmen J, Lindow M, Silahtaroglu A, et al. Antagonism of microRNA-122 in mice by systemically administered LNA-antimiR leads to up-regulation of a large set of predicted target mRNAs in the liver. Nucleic Acids Res. 2008; 36:1153-1162. [PubMed: 18158304]

197. Esau C, Davis S, Murray SF, et al. miR-122 regulation of lipid metabolism revealed by in vivo antisense targeting. Cell Metab. 2006; 3:87-98. [PubMed: 16459310]

198. Elmen J, Lindow M, Schutz S, et al. LNA-mediated microRNA silencing in non-human primates. Nature. 2008; 452:896-899. [PubMed: 18368051]

199. Ebert MS, Sharp PA. MicroRNA sponges: progress and possibilities. RNA. 2010; 16:2043-2050. [PubMed: 20855538]

200. Lanford RE, Hildebrandt-Eriksen ES, Petri A, et al. Therapeutic silencing of microRNA-122 in primates with chronic hepatitis C virus infection. Science. 2010; 327:198-201. [PubMed: 19965718]

201. Meister G, Tuschl T. Mechanisms of gene silencing by double-stranded RNA. Nature. 2004; 431:343-349. [PubMed: 15372041] 


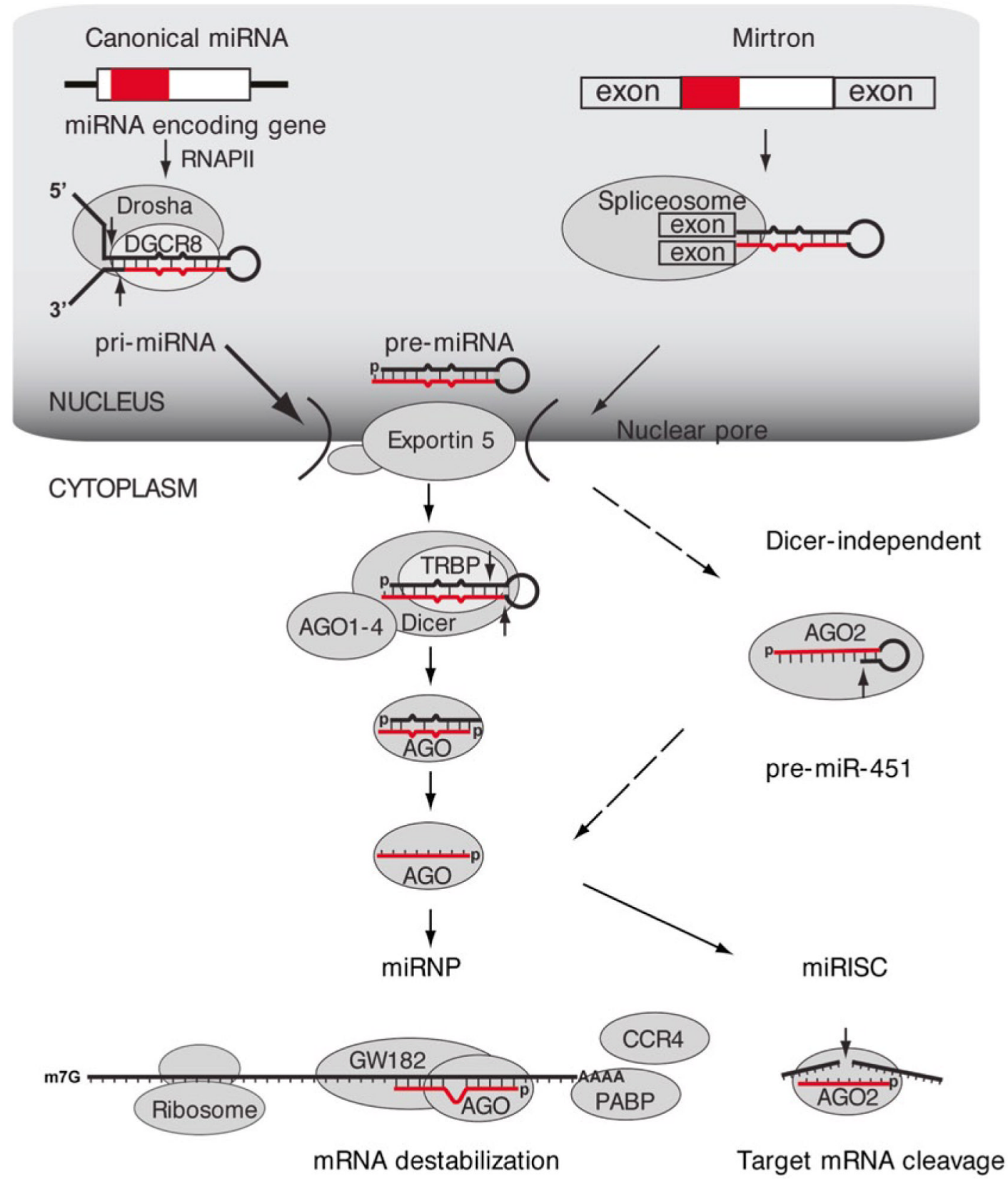

Fig. 1.1.

miRNA biogenesis pathway. miRNAs are transcribed by RNAPII to produce pri-miRNAs. Canonical miRNAs are processed by the endoribonuclease Drosha in partnership with its RBP partner DGCR8; mirtrons are instead processed by the spliceosome. The processed premiRNA is transported to the cytoplasm through an export complex consisting of exportin 5. The pre-miRNA is subsequently processed in the cytoplasm by another endoribonuclease Dicer in partnership with its RBP partner TRBP to form the final 21-23 nucleotide miRNA product. miR-451 is not processed by Dicer, but is rather cleaved by AGO2. Mature miRNAs (indicated in red) are then incorporated into AGO 1 through 4, forming miRNPs, also known as miRISC. miRNPs also incorporate other proteins, such as GW182. miRNPs are thought to direct miRNA mediated destabilization (i.e. through interaction with CCR4) 
or miRNA mediated translational repression (i.e. through interaction with ribosomes) of miRNAs without perfectly complementary mRNA targets. miRISC is thought to direct AGO2 catalyzed target mRNA cleavage of miRNA fully or nearly fully complementary mRNA targets 
A

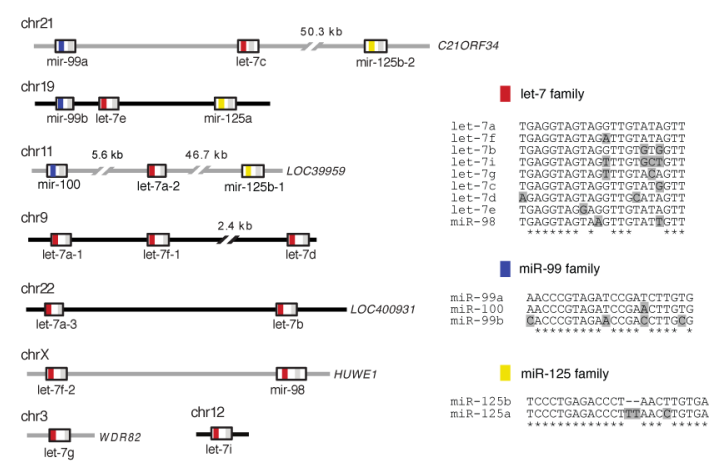

B

chrs
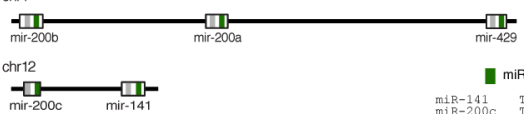

C
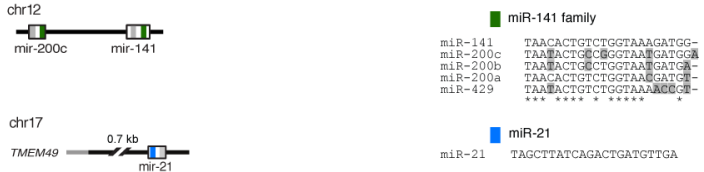

D
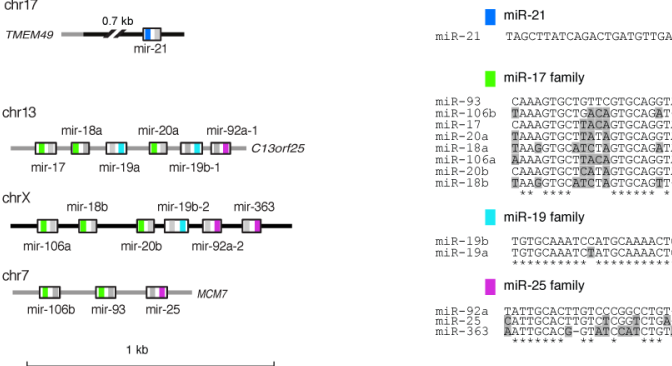

|I miR-17 tamily

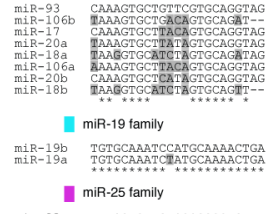

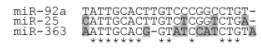

Fig. 1.2.

miRNA genomic and functional organization. The genomic and functional organization of four miRNA clusters is clarified: (a) let-7/mir-98 cluster, (b) mir-141/mir-200a cluster, (c) mir-21 cluster and (d) mir-17-92 cluster. The genomic locations for each of the miRNA members are defined. Grey lines denote intronic regions. miRNA mature sequences are color coded according to the sequence family they belong to (i.e. in the let-7/mir-98 cluster red signifies the let-7 sequence family). The star sequence is defined with a grey bar. The sequence families are depicted as sequence alignments compared to the most highly expressed miRNA family member shown on top, based on profiles of over 1,000 human specimens [39]. Shaded residues denote differences from the most highly expressed miRNA family member 


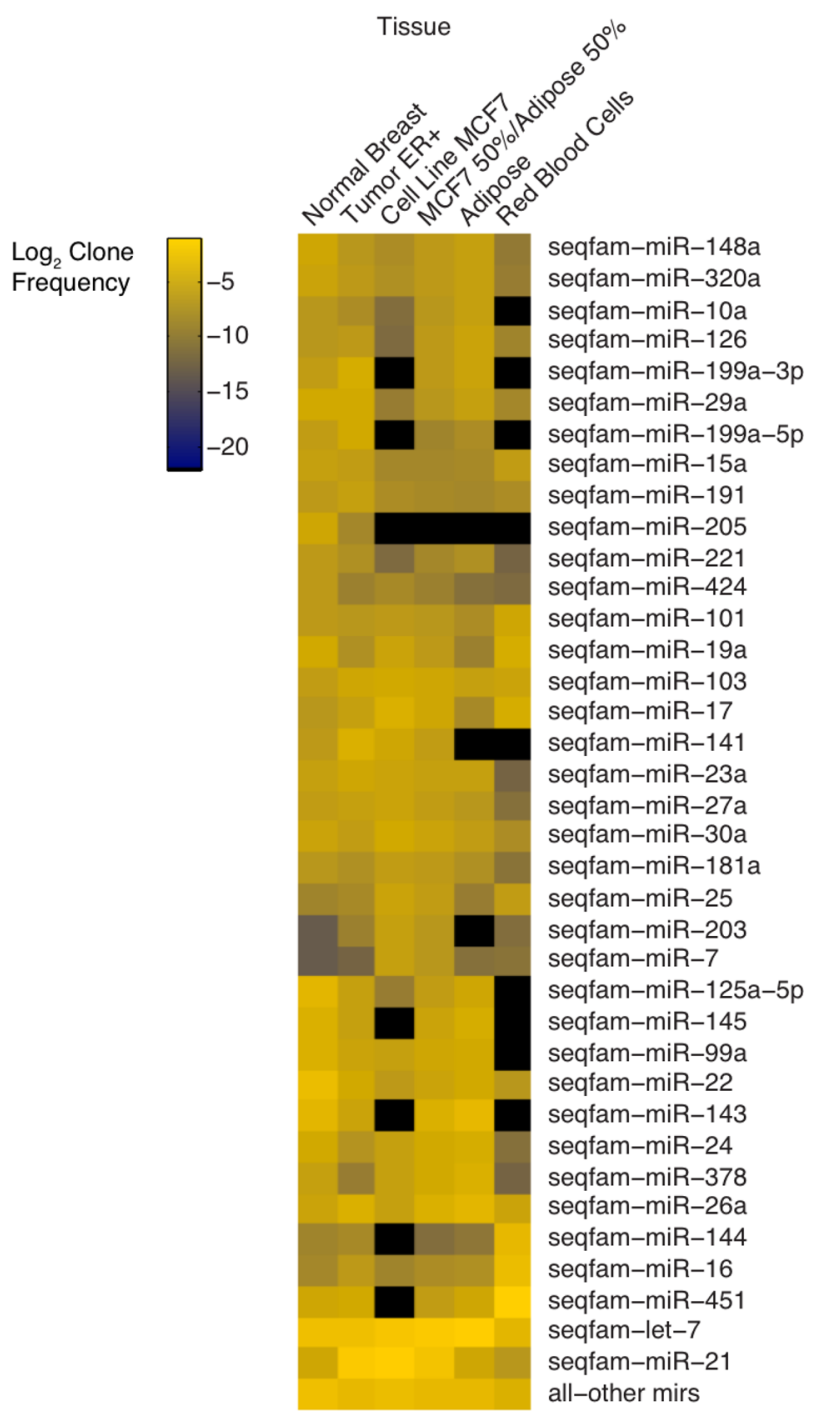

Fig. 1.3.

miRNA breast tumor and cell line profiles. Comparison of abundance profiles of the top expressed miRNA sequence families of normal breast, an estrogen receptor positive invasive ductal carcinoma breast tumor (ER+), the MCF7 ductal derived cell line, human subcutaneous adipose tissue and red blood cells 
Table 1.1

Some of the most common cancer-associated miRNAs

\begin{tabular}{|c|c|c|c|c|}
\hline miRNA & Tissue type specificity & Chromosomal location & Property & Malignancy \\
\hline let-7/98 cluster & Ubiquitous & $\begin{array}{l}\text { Multiple members } \\
\text { (chromosomes } 3,9,11,19,21 \text {, } \\
22, X \text { ) }\end{array}$ & TS & $\begin{array}{l}\text { CLL [136], lymphoma [137], gastric [138], } \\
\text { lung [139], prostate [9], breast [140], } \\
\text { ovarian [138], colon [138], leiomyoma } \\
\text { [138], melanoma [138] }\end{array}$ \\
\hline mir-15a/16-1 cluster & Ubiquitous & $13 q 14.2$ & TS & $\begin{array}{l}\text { CLL [141], lymphoma [9], multiple } \\
\text { myeloma [9], pituitary adenoma [142], } \\
\text { prostate [142], pancreatic [142] }\end{array}$ \\
\hline mir-17-92 cluster & Ubiquitous & $\begin{array}{l}\text { Multiple members } \\
\text { (chromosomes 7, 13, X) }\end{array}$ & OG & $\begin{array}{l}\text { Lymphoma [143], multiple myeloma [9], } \\
\text { lung [139], colon [143], medulloblastoma } \\
\text { [144], breast [140], prostate [145] }\end{array}$ \\
\hline miR-21 & Ubiquitous & $17 \mathrm{q} 23.1$ & OG & $\begin{array}{l}\text { Lymphoma, breast, lung, prostate, gastric, } \\
\text { cervical, head and neck, colorectal, } \\
\text { glioblastoma (for all: [146]) }\end{array}$ \\
\hline \multirow[t]{2}{*}{ miR-26a } & Ubiquitous & $\begin{array}{l}3 \mathrm{p} 22.2(-1) \\
12 \mathrm{q} 14.1(-2)\end{array}$ & TS & $\begin{array}{l}\text { Lymphoma [147], hepatocellular carcinoma } \\
\text { [148], thyroid carcinoma [149] }\end{array}$ \\
\hline & & & OG & Glioblastoma $[53,150]$ \\
\hline $\mathrm{miR}-34 \mathrm{a} / \mathrm{b} / \mathrm{c}$ & Ubiquitous & $\begin{array}{l}1 \mathrm{p} 36.22(\mathrm{a}) \\
11 \mathrm{q} 23.1(\mathrm{~b}) \\
11 \mathrm{q} 23.1(\mathrm{c})\end{array}$ & TS & $\begin{array}{l}\text { CLL [136], lymphoma [9], pancreatic [9], } \\
\text { colon [9], neuroblastoma [151], } \\
\text { glioblastoma [152] }\end{array}$ \\
\hline miR-155 & Hematopoietic system & $21 \mathrm{q} 21.3$ & OG & $\begin{array}{l}\text { Lymphoma (i.e. Burkitt's, Hodgkin's, non- } \\
\text { Hodgkin's) [9], CLL ([9], [18]), breast } \\
{[140] \text {, lung [9], colon [9], pancreatic [9] }}\end{array}$ \\
\hline \multirow[t]{2}{*}{ mir-141/200a cluster } & Epithelial specific & $\begin{array}{l}\text { Multiple members } \\
\text { (chromosomes 1, 12) }\end{array}$ & TS & $\begin{array}{l}\text { Breast [140, 153], renal clear cell carcinoma } \\
\text { [154], gastric [155], bladder [156] }\end{array}$ \\
\hline & & & OG/TS & Ovarian [157-159] \\
\hline \multirow[t]{2}{*}{ miR-205 } & Epithelial specific & $1 \mathrm{q} 32.2$ & TS & $\begin{array}{l}\text { Prostate [160, 161], bladder [162], breast } \\
{[153,163,164], \text { esophageal }[165]}\end{array}$ \\
\hline & & & OG & Ovarian [166] \\
\hline miR-206 & Skeletal muscle specific & $6 \mathrm{p} 12.2$ & TS & Rhabdomyosarcoma [30], breast [167] \\
\hline \multirow[t]{2}{*}{$\operatorname{miR}-9$} & Nervous system specific & $\begin{array}{l}1 \mathrm{q} 22(-1) \\
5 \mathrm{q} 14.3(-2) \\
15 \mathrm{q} 26.1(-3)\end{array}$ & TS & Medulloblastoma [168], ovarian [169] \\
\hline & & & OG/TS & Breast $[66,170,171]$ \\
\hline
\end{tabular}

miRNAs that are up- or down-regulated in malignancies are respectively referred to as oncogenic $(O G)$ or tumor-suppressor (TS), but their role in malignancy is not always experimentally validated. Given the number of manuscripts providing evidence for the role of each miRNA based on patient, cell culture or animal model studies, reviews are often cited instead of original reports to limit the number of references, and only a few selected reports are presented if no review is presented 